\title{
Validation of a Filipino Version of the Cardiff Acne Disability Index
}

\author{
Winlove P. Mojica, ${ }^{1}$ Lily Lyralin DL. Laconico, ${ }^{1}$ Belen L. Dofitas ${ }^{1}$ and Rowena F. Genuino ${ }^{2}$ \\ ${ }^{1}$ Out-patient Department, Section of Dermatology, College of Medicine and Philippine General Hospital, University of the Philippines Manila \\ ${ }^{2}$ Department of Anatomy, College of Medicine, University of the Philippines Manila
}

\begin{abstract}
Objective. This study assessed the reliability and validity of a Filipino version of the Cardiff Acne Disability Index.

Methods. In Phase 1, the Cardiff Acne Disability Index (CADI) was translated into Filipino as the Cardiff Indeks ng Kapansanan ng may Tigyawat (CIKT) following international guidelines on translation and cultural adaptation, and passed a cognitive debriefing test (a form of face validity testing). In Phase 2, the CIKT was administered to 400 public high school students (11-18 years old). Cronbach's a was used to measure reliability while construct validity was determined by comparing 1) the CIKT scores of adolescents with acne and those without acne and 2) the CIKT scores with the scores of the Taluntunan ng Kalidad ng Buhay na Hinggil sa Dermatolohiya (TKBD), which is a validated Filipino version of the Dermatology Life Quality Index.
\end{abstract}

Results. Cronbach's a showed an adequate internal consistency of 0.7 . The linear regression coefficient for those with and without acne was $0.98(\mathrm{Cl} 0.59,1.37)(\mathrm{p}=0.00)$ while the Spearman correlation showed a positive correlation between the CIKT and the TKBD $(0.58, \mathrm{p}=0.00)$, both indicating validity.

Conclusion. The CIKT is a reliable and valid Filipino translation of the CADI.

Key Words: Acne vulgaris, quality of life, disability evaluation, translation, Filipino

\section{Introduction}

Acne is a chronic inflammatory condition of the pilosebaceous unit which is common in adolescents. Although considered trivial by many, it has been shown that acne patients suffer from social, psychological and emotional problems that are as great as those reported by patients with chronic disabling asthma, epilepsy, diabetes, back pain, or

Presented and won First Place at the Philippine Dermatological Society Annual Residents' Research Forum Non-experimental Category, November 2012, Crowne Plaza Hotel, Ortigas, Quezon City, Philippines.

Corresponding author: Winlove P. Mojica, MD

Out-patient Department

Section of Dermatology

Philippine General Hospital

University of the Philippines Manila

Padre Faura Street, Ermita, Manila, 1000 Philippines

Telephone: +63922 8907869/+63917 6202006

Email: winlove_m@yahoo.com arthritis. ${ }^{1,2}$ Quality of life (QOL) is a broad concept encompassing both the positive and negative aspects of life. ${ }^{3}$ It includes domains of health, jobs, housing, schools and the neighborhood. It is difficult to measure since quality of life may be viewed differently among individuals and cultures. Health-related quality of life (HRQOL) spans the physical and mental aspects of life that affect health. ${ }^{4}$ Its analysis produces a multitude of advantages, and measurements can bridge gaps between social, mental and medical services. ${ }^{4}$ HRQOL measurements can help with the following: 1) determine the burden of preventable disease, injuries and disabilities, 2) give clues on its association with health risk factors, 3) identify special populations with relatively poor perceived health, and 4) guide interventions to improve their situations and prevent more serious complications. ${ }^{4}$ In addition, it is useful for health policy development, allocating resources and monitoring the effectiveness of

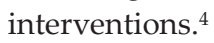

The Cardiff Acne Disability Index (CADI) ${ }^{5}$ (Appendix 1) is an acne-specific QOL measure developed in the United Kingdom, and designed for teenagers and young adults. It is a validated five-item questionnaire which addresses the psychological, social and emotional consequences of acne. It is a shortened version of the longer Acne Disability Index and can be completed rapidly and without difficulty, thus making it simple to use in clinical practice. ${ }^{6}$ The patients' responses to the CADI questionnaire have been shown to be significantly correlated with the clinician's assessment of acne severity. ${ }^{5}$ Its use may help in identifying acne patients with high levels of functional disability who would potentially need more aggressive treatment or supportive counselling. It is also necessary for measuring patient outcomes in interventional research. The CADI has been translated, cross-culturally adapted and validated in 14 languages: Arabic, Cantonese 7 , Chinese, Czech, Dutch, French, Hindi, Kurdish, Malayam, Moroccan, Persian8, Portuguese, Serbian and Ukranian.

The purpose of this study was to translate the CADI into Filipino using published guidelines on translation and cross-cultural adaptation as well as to test the reliability and validity of the translated version. Currently, the tool has not been translated into Filipino. Such instrument can help Filipino dermatologists individualize their approach to the management of acne based not just on the clinical presentation of the lesions but also on the functional disability of the patient. A Filipino tool will also serve as a 
standard instrument that can be used in studies on Filipino patients to assess baseline functioning and satisfaction on acne treatments.

\section{Methods}

Written permission was obtained from the original instrument developers to translate the CADI into Filipino. This study was divided into two phases. The Filipino translation and cross-cultural adaptation of the CADI was done in Phase 1 from March to May 2012 followed by reliability and validity testing in Phase 2 from May to June 2012. The study protocol was approved by the hospital ethics review committee and respondents were only enrolled to the study after completion of assent and consent forms.

\section{Phase 1: Translation and Cultural Adaptation}

\section{Preparation}

The instrument developers were involved by giving guidelines and clarifying ambiguities throughout the translation process. The investigators sought permission from the Division of City Schools Manila and school principal to conduct Phases 1 and 2 of the study in a secondary public co-educational school.

\section{Forward translation}

The study followed nine steps out of the 10-step process recommended by Wild et al. and Guillemin et al. for the translation and cultural adaptation of health-related QOL instruments.9,10 Two grade school teachers who were native speakers of Filipino, fluent in English and residing in the Philippines were asked to do independent forward translations of the CADI to Filipino. The investigators briefed the translators with a clear explanation to produce a conceptual translation rather than a literal translation. The translators were instructed to produce translations that would be easily understood by the general lay population: wordings should be understandable by children as young as 10 years old, using short sentences with key words kept as simple as possible, using active rather than passive voice, using repeated nouns instead of pronouns, and specific rather than general terms. The translators were asked to avoid using metaphors, the subjective mode and sentences containing words that suggest different actions.

\section{Reconciliation}

The two forward translators and the investigators discussed and reconciled the translations into a single forward translation. Discrepancies between the original independent translations were resolved, and agreement between individual speech habits and preferences were sought. Several alternative translations were done until one final reconciled forward translation in Filipino was produced for back translation to English.

\section{Back Translation}

Four translators, who were different people from the forward translators but with the same qualifications, were asked to independently translate the reconciled Filipino translation back into English. This was meant to be a quality control step such that the same meaning is derived when the translation is moved back into the source language using a conceptual back translation rather than a literal one. One reconciled back translation was produced for review.

\section{Back Translation Review}

A review of the back translation against the source language was done by the investigators to identify any discrepancies. Problematic items were discussed with the back translators and the Filipino translation was refined. The original instrument developers were asked to assess the equivalence of each item as well as each graded response between the original and back-translated versions. Once the back translation was approved, the Filipino translation was also considered approved by the original instrument developers.

\section{Cognitive Debriefing}

A secondary public school was chosen for cognitive debriefing due to convenience to the investigators. The newly translated measure was pre-tested for face validity on a group of 10 volunteers. An announcement was made at the school's morning flag ceremony regarding the study. Interested students who were minors (ages 10-17 years) were given an informed consent form to be signed by their parents and an assent form to be filled out by the students. Non-minors directly filled out the consent form prior to the administration of the instrument. The Physical Education Teachers recruited the students and handed out the forms. Upon presentation of a written consent/parental consent/assent form, eligible students were enrolled in the study.

Eligible respondents were either male or female between 10 to 19 years old, and understood both Filipino and English. Each respondent was asked to rate each item in the Filipino questionnaire as to comprehensibility, unambiguity and relevance to social context. A five-point Likert scale was used (1-strongly disagree; 2-disagree; 3neither agree nor disagree; 4-agree; 5-strongly agree). A minimum average score of 4 for each aspect was set to be acceptable.

\section{Review of Cognitive Debriefing Results and Finalization}

The investigators reviewed the cognitive debriefing results. Clarifications were sought from the instrument developers and revisions to the Filipino translation were agreed upon. A final version of the Filipino translation, which was named the Cardiff Indeks ng Kapansanan ng may Tigyawat (CIKT), was prepared prior to Phase 2. 


\section{Phase 2: Reliability and Validity Testing}

Phase 2 was conducted at the same secondary public school in Manila. An announcement to join the study was made and interested students were asked to fill out the assent and consent forms prior to enrolment in the study. The Physical Education Teachers recruited the students and handed out the forms. The eligible students were male or female, 10 to 19 years old, and fluent in English and Filipino. A total of 280 respondents (95\% Sensitivity, 90\% Specificity, $50 \%$ prevalence, 0.05 precision) was required for the study. From 280 respondents, 140 with acne (Group A) and 140 without acne (Group B) were needed for the Known-groups Method ${ }^{11}$ validity analysis.

The CIKT was self-administered to enrolled participants during their Physical Education class. The primary investigator was present to collect the accomplished instruments. Each question had four graded responses (A to D) with corresponding weighted scores of 3 to 0 following the scoring system of the original instrument. The total CIKT score was calculated by summing the individual scores of each question resulting in a possible maximum score of 15 and a minimum of 0 . The higher the score, the more the quality of life is impaired. Currently, there are no studies that have been done to indicate which scores are mild, moderate or severe impairment of QOL.

Reliability was tested through Cronbach's alpha, an internal consistency measure. A value of 0.7 was considered acceptable. On the other hand, two tests were performed to evaluate construct validity. The CIKT scores of the respondents with and without acne were correlated through linear regression, known as the Known-groups Method. ${ }^{11}$ Also, through the Convergence Method ${ }^{11}$, respondents 16 years and older were asked to answer a second questionnaire, the Taluntunan ng Kalidad ng Buhay na Hinggil sa Dermatolohiya (TKBD) (Appendix 2), a validated Tagalog version of the Dermatology Life Quality Index (DLQI) to further assess validity. The DLQI is the most frequently used quality of life measure in clinical studies in dermatology. ${ }^{12}$ Scores from the TKBD and the CIKT were correlated using Spearman correlation coefficient. A correlation coefficient of $\geq 0.4$ was considered acceptable.

\section{Results}

A total of three forward- and back-translations were done before the final Filipino version of the CADI was approved by the investigators and instrument developers. The cognitive debriefing results showed an acceptable minimum average of 4 for comprehensibility, unambiguity and relevance to the Filipino context / culture for each of the questionnaire items (Table 1). The final version of the CIKT (Table 2) was approved for use for Phase 2 by the investigators and instrument developers.

A total of 415 students were invited to join Phase 2 of the study but only 402 respondents completed the assent and consent forms and were subsequently enrolled. Two failed to complete the CIKT for unknown reasons and were dropped from the study thus data analysis was limited to

Table 1. Cognitive debriefing: Mean scores for face validity $(\mathrm{N}=10)$

\begin{tabular}{cccc}
\hline Question \# & Comprehensible & Unambiguous & Relevant to Filipino Context/Culture \\
\hline $\mathbf{1}$ & 4.6 & 4.7 & 4.3 \\
$\mathbf{2}$ & 4.6 & 4.6 & 4.6 \\
$\mathbf{3}$ & 4.4 & 4.3 & 4.9 \\
$\mathbf{4}$ & 4.6 & 4.4 & 4.6 \\
$\mathbf{5}$ & 4.5 & 4.4 & 4.1 \\
\hline
\end{tabular}

Table 2. Cardiff Indeks ng Kapansanan ng may Tigyawat (CIKT)

\begin{tabular}{|c|c|c|}
\hline $\begin{array}{l}\text { 1. Nitong nakaraang buwan, ikaw ba ay naging agresibo, bigo o napahiya dahil sa pagkakaroon ng } \\
\text { tigyawat? }\end{array}$ & $\begin{array}{l}\square \\
\square \\
\square \\
\square\end{array}$ & $\begin{array}{l}\text { (a) Labis-labis } \\
\text { (b) Labis } \\
\text { (c) Bahagya } \\
\text { (d) Hindi }\end{array}$ \\
\hline $\begin{array}{l}\text { 2. Sa iyong palagay, naging hadlang ba ang pagkakaroon mo ng tigyawat sa pakikisalamuha mo sa } \\
\text { kapwa, sa pagdalo mo sa mga okasyon, o sa pakikitungo mo sa ibang kasarian sa nakaraang buwan? }\end{array}$ & $\begin{array}{l}\square \\
\square \\
\square \\
\square\end{array}$ & $\begin{array}{l}\text { (a) Masyado, lahat ng gawain ko ay apektado } \\
\text { (b) Madalas, halos lahat ng gawain ko ay apektado } \\
\text { (c) Minsan, sa ilang mga gawain } \\
\text { (d) Hindi }\end{array}$ \\
\hline $\begin{array}{l}\text { 3. Sa nakaraang buwan, umiwas ka ba sa paggamit ng mga pampublikong bihisan o pagsuot ng } \\
\text { damit panlangoy dahil sa iyong tigyawat? }\end{array}$ & $\begin{array}{l}\square \\
\square \\
\square \\
\square\end{array}$ & $\begin{array}{l}\text { (a) Palagi } \\
\text { (b) Madalas } \\
\text { (c) Paminsan-minsan } \\
\text { (d) Hindi }\end{array}$ \\
\hline $\begin{array}{l}\text { 4. Paano mo mailalarawan ang iyong damdamin tungkol sa itsura ng iyong balat nitong nakaraang } \\
\text { buwan? }\end{array}$ & $\begin{array}{l}\square \\
\square \\
\square \\
\square\end{array}$ & $\begin{array}{l}\text { (a) Sobrang malungkot at miserable } \\
\text { (b) Madalas na nababahala } \\
\text { (c) Paminsan-minsang nababahala } \\
\text { (d) Hindi nababahala }\end{array}$ \\
\hline 5. Sa iyong palagay, gaano kalala ang iyong tigyawat sa kasalukuyan? & $\begin{array}{l}\square \\
\square \\
\square \\
\square\end{array}$ & $\begin{array}{l}\text { (a) Pinakamalalang problema } \\
\text { (b) Isang malalang problema } \\
\text { (c) Isang magaang problema } \\
\text { (d) Hindi problema }\end{array}$ \\
\hline
\end{tabular}


400 respondents with a $99.5 \%$ response rate. The remaining respondents answered all the items. Completion time for the CIKT was about 1.5 minutes.

The age range of the participants was 11-18 years with a mean age of 14 years ( $\mathrm{SD} \pm 1.13$ years). The participants were $59 \%$ females and $41 \%$ males. Those with acne accounted for 65\% (Group A, $\mathrm{n}=259$ ) of the respondents while 35\% (Group $\mathrm{B}, \mathrm{n}=141$ ) had no acne.

Internal consistency of the CIKT was acceptable with Cronbach's alpha of 0.7 . The linear regression coefficient for those with and without acne was 0.98 (CI 0.59-1.37, p = 0.00) while there was a statistically significant positive correlation of the CIKT with the TKBD with a coefficient of $0.58(\mathrm{p}=0.00)$.

\section{Discussion}

There are two approaches in developing health-related quality of life measures. The first is to develop a new measure but this method is time-consuming since it focuses on the conceptualization of the instrument and selection and reduction of its items. ${ }^{10}$ The second approach is to translate an already validated measure. This is less tedious, however, a simple literal translation may not produce an equivalent tool because of language, cultural and health behavior differences in different populations. ${ }^{10}$ In this study, international guidelines for translation and cross-cultural adaptation were followed in translating the CADI to Filipino.

Health-related QOL measures are meant to be used by lay people therefore translators should also be as ordinary as possible to prevent an overly-academic translation unfit for general public use. To ensure this, teachers have been suggested to be good examples of translators because they are exposed to different levels of language abilities. ${ }^{13}$ This study involved grade school teachers and a team of doctors and administrative clerks during the forward and back translations, respectively. The investigators and instrument developers were highly-involved in the fine-tuning of the instrument before the final translation of CADI.

A total of 400 students were included in Phase 2 of the study. The choice of respondents from a secondary school rather than in a hospital setting prevented an overrepresentation of a population of acne patients who are already constantly bothered by their skin condition causing them to seek medical help.

Successful translation and cross-cultural adaptation of survey instruments depend on the reliability and validity of the newly translated tool. Reliability is equated with measuring an instrument's consistency or stability. ${ }^{11}$ In this study, internal consistency was assessed through Cronbach's $\alpha$ using data from Phase 2. A value of 0.7 confirmed that the tool is reliable. Internal consistency testing surmounts the disadvantages of test-retest and alternative forms method of reliability testing. ${ }^{11}$
A measuring instrument is valid if it accurately measures the construct it actually wants to measure. ${ }^{11}$ In this study, three tests confirmed the validity of CIKT. Face validity was confirmed in the cognitive debriefing phase. Construct validity implies that the instrument measures the concept in question and not some other concept and that the concept is actually being measured accurately. ${ }^{11}$ The Known Groups Method showed that those with acne, a group assumed to exhibit higher functional disability than those without acne, had scores higher than the non-acne group by almost 1 point. The tool therefore is able to differentiate between acne and non-acne groups based on functional disability. The Convergence Method on the other hand ensures that the instrument in question measures the same construct in comparison to an already validated instrument measuring the same construct. ${ }^{11}$ The positive correlation coefficient of $0.58(\mathrm{p}=0.00)$ between the CIKT and the TKBD confirms construct validity. The positive correlation of the CIKT and TKBD is similar to the results of a Chinese study which also showed a positive correlation of the Chinese CADI and Chinese DLQI with a coefficient of $0.58(p=0.04){ }^{7}$

\section{Conclusion and Recommendation}

This validation study followed published international guidelines on translation and cross-cultural adaptation of quality of life measures. The large sample of subjects assured that the resultant questionnaire, the CIKT, is a valid and reliable Filipino version of the CADI. Moreover, the choice of internal consistency testing combined with three tests for validity all showed positive results, strengthening this study's findings of a successful translation. Translation of the CADI to other major dialects in the Philippines, such as Visayan, and further validation in other settings (hospital or community) are recommended.

\section{Statement of Authorship}

All authors have approved the final version submitted.

\section{Author Disclosure}

All the authors declared no conflicts of interest.

\section{Funding Source}

This paper was funded by the personal funds of the primary author.

\section{References}

1. Koo J. The psychosocial impact of acne: patients' perceptions. J Am Acad Dermatol. 1995; 32(5 Pt 3):S26-30.

2. Mallon E, Newton J, Klassen A, Stewart-Brown S, Ryan T, Finlay A. The quality of life in acne: a comparison with general medical conditions using generic questionnaires. Br J Dermatol. 1999; 140(4):672-6.

3. The World Health Organization Quality of Life Assessment (WHOQOL): development and general psychometric properties. Soc Sci Med. 1998; 46(12):1569-85. 
4. Centers for Disease Control and Prevention, Health-Related Quality of Life (HRQOL) [Online]. [cited 2012 Sep]. Available from http://www. cdc.gov/hrqol/concept.htm.

5. Motley RJ, Finlay AY. Practical use of a disability index in the routine management of acne. Clin Exp Dermatol. 1992; 17(1):1-3.

6. Cardiff University Department of Dermatology Quality of Life Questionnaires, Cardiff Acne Disability Index (CADI) [Online]. [cited 2011 Jan]. Available from http://www.cardiff.ac.uk/dermatology/ quality-of-life/cardiff-acne-disability-index-cadi/.

7. Law MP, Chuh AA, Lee A. Validation of a Chinese version of the Cardiff Acne Disability Index. Hong Kong Med J. 2009; 15(1):12-7.

8. Aghaei S, Mazharinia N, Jafari P, Abbasfard Z. The Persian version of the Cardiff Acne Disability Index. Reliability and validity study. Saudi Med J. 2006; 27(1):80-2.

9. Wild D, Grove A, Martin M, et al. Principles of Good Practice for the Translation and Cultural Adaptation Process for Patient-Reported Outcomes (PRO) Measures: report of the ISPOR Task Force for Translation and Cultural Adaptation. Value Health. 2005; 8(2):94-104.
10. Guillemin F, Bombardier C, Beaton D. Cross-cultural adaptation of health-related quality of life measures: literature review and proposed guidelines. J Clin Epidemiol. 1993; 46(12):1417-32.

11. Smith M. Contemporary Communication Research Methods. Belmont, California: Wadsworth Publishing Company; 1989. pp. 46-50.

12. Cardiff University Department of Dermatology Quality of Life Questionnaires, Dermatology Quality of Life Index (DLQI) [Online]. [cited 2016 July]. Available from http://sites.cardiff.ac.uk/dermatology/ quality-of-life/dermatology-quality-of-life-index-dlqi/.

13. Swaine-Verdier A, Doward LC, Hagell P, Thorsen H, McKenna SP. Adapting quality of life instruments. Value Health. 2004; 7 Suppl 1:S27-30.

\section{Appendix}

\section{Appendix 1. Cardiff Acne Disability Index (CADI)}

\begin{tabular}{|c|c|c|}
\hline $\begin{array}{l}\text { 1. As a result of having acne, during the last month have you been aggressive, frustrated or } \\
\text { embarrassed? }\end{array}$ & $\begin{array}{l}\square \\
\square \\
\square \\
\square\end{array}$ & $\begin{array}{l}\text { (a) Very much indeed } \\
\text { (b) A lot } \\
\text { (c) A little } \\
\text { (d) Not at all }\end{array}$ \\
\hline $\begin{array}{l}\text { 2. Do you think that having acne during the last month interfered with your daily social life, social } \\
\text { events or relationships with members of the opposite sex? }\end{array}$ & $\begin{array}{l}\square \\
\square \\
\square \\
\square\end{array}$ & $\begin{array}{l}\text { (a) Severely, affecting all activities } \\
\text { (b) Moderately, in most activities } \\
\text { (c) Occasionally or in only some activities } \\
\text { (d) Not at all }\end{array}$ \\
\hline $\begin{array}{l}\text { 3. During the last month have you avoided public changing facilities or wearing swimming costumes } \\
\text { because of your acne? }\end{array}$ & $\begin{array}{l}\square \\
\square \\
\square \\
\square\end{array}$ & $\begin{array}{l}\text { (a) All of the time } \\
\text { (b) Most of the time } \\
\text { (c) Occasionally } \\
\text { (d) Not at all }\end{array}$ \\
\hline 4. How would you describe your feelings about the appearance of your skin over the last month? & $\begin{array}{l}\square \\
\square \\
\square \\
\square\end{array}$ & $\begin{array}{l}\text { (a) Very depressed and miserable } \\
\text { (b) Usually concerned } \\
\text { (c) Occasionally concerned } \\
\text { (d) Not bothered }\end{array}$ \\
\hline 5. Please indicate how bad you think your acne is now: & $\begin{array}{l}\square \\
\square \\
\square \\
\square\end{array}$ & $\begin{array}{l}\text { (a) The worst it could possibly be } \\
\text { (b) A major problem } \\
\text { (c) A minor problem } \\
\text { (d) Not a problem }\end{array}$ \\
\hline
\end{tabular}


Appendix 2. Tagalog Dermatology Life Quality Index (DLQI)

TALUNTUNAN NG KALIDAD NG BUHAY NA HINGGIL SA DERMATOLOHIYA

Ang layunin ng palatanungang ito ay upang masukat kung gaano naaapektuhan ng iyong problema sa balat ang iyong buhay sa NAKARAANG LINGGO. Mangyaring lagyan ng tsek ang isang kahon para sa bawat tanong.

\begin{tabular}{|c|c|c|c|c|}
\hline 1. Sa nakaraang linggo, gaano kakati, kakirot, kasakit o kahapdi ang iyong balat? & \begin{tabular}{|l|} 
Labis-labis \\
Labis \\
Bahagya \\
Walang-wala
\end{tabular} & $\begin{array}{l}\square \\
\square \\
\square \\
\square\end{array}$ & & \\
\hline $\begin{array}{l}\text { 2. Sa nakaraang linggo, gaano ka napahiya o may labis na kamalayan sa tingin ng ibang tao dahilsa } \\
\text { iyong balat? }\end{array}$ & $\begin{array}{l}\text { Labis-labis } \\
\text { Labis } \\
\text { Bahagya } \\
\text { Walang-wala }\end{array}$ & $\begin{array}{l}\square \\
\square \\
\square \\
\square\end{array}$ & & \\
\hline $\begin{array}{l}\text { 3. Sa nakaraang linggo, gaano nakasagabal ang iyong balat sa iyong pamimili o pag-aasikaso sa } \\
\text { iyong bahay o bakuran? }\end{array}$ & \begin{tabular}{|l} 
Labis-labis \\
Labis \\
Bahagya \\
Walang-wala \\
\end{tabular} & $\begin{array}{l}\square \\
\square \\
\square \\
\square\end{array}$ & Hindi angkop & $\square$ \\
\hline 4. Sa nakaraang linggo, gaano nakaimpluwensya ang iyong balat sa mga damit na iyong sinusuot? & \begin{tabular}{|l|} 
Labis-labis \\
Labis \\
Bahagya \\
Walang-wala \\
\end{tabular} & $\begin{array}{l} \\
\square \\
\square \\
\square \\
\square\end{array}$ & Hindi angkop & $\square$ \\
\hline $\begin{array}{l}\text { 5. Sa nakaraang linggo, gaano nakaapekto ang iyong balat sa anumang mga gawaing } \\
\text { pakikisalalamuha sa tao or panlibangan? }\end{array}$ & \begin{tabular}{|l|} 
Labis-labis \\
Labis \\
Bahagya \\
Walang-wala
\end{tabular} & $\begin{array}{l}\square \\
\square \\
\square \\
\square\end{array}$ & Hindi angkop & $\square$ \\
\hline 6. Sa nakaraang linggo, gaano nagpahirap ang iyong balat na makalaro ka sa anumang isport? & \begin{tabular}{|l|} 
Labis-labis \\
Labis \\
Bahagya \\
Walang-wala
\end{tabular} & $\begin{array}{l}\square \\
\square \\
\square \\
\square \\
\square\end{array}$ & Hindi angkop & 口 \\
\hline & $\begin{array}{l}\text { Oo } \\
\text { Hindi }\end{array}$ & $\begin{array}{ll}\square \\
\square\end{array}$ & Hindi angkop & 口 \\
\hline $\begin{array}{l}\text { Kung "Hindi”, sa nakaraang linggo, gaano nagiging problema ang iyong balat sa trabaho } \\
\text { o pag-aaral? }\end{array}$ & \begin{tabular}{|l|} 
Labis \\
Bahagya \\
Walang-wala
\end{tabular} & $\begin{array}{l}\square \\
\square \\
\square\end{array}$ & & \\
\hline $\begin{array}{l}\text { 8. Sa nakaraang lingo, gaano nakalikha ng mga problema ang iyong balat sa iyong kapareha o sa } \\
\text { sinuman sa iyong mga malalapit na kaibigan o kamag-anak? }\end{array}$ & \begin{tabular}{|l|} 
Labis-labis \\
Labis \\
Bahagya \\
Walang-wala
\end{tabular} & $\begin{array}{l}\square \\
\square \\
\square \\
\square\end{array}$ & Hindi angkop & 口 \\
\hline $\begin{array}{l}\text { 9. Sa nakaraang lingo, gaano naging sanhi ang iyong balat ng anumang mga kahirapan sa } \\
\text { pakikipagtalik? }\end{array}$ & \begin{tabular}{|l|} 
Labis-labis \\
Labis \\
Bahagya \\
Walang-wala
\end{tabular} & $\begin{array}{l}\square \\
\square \\
\square \\
\square\end{array}$ & Hindi angkop & 口 \\
\hline $\begin{array}{l}\text { 10. Sa nakaraang linggo, gaano naging problema ang paggamot sa iyong balat, halimbawa, gawing } \\
\text { makalat ang iyong tahanan o sa pag-aksaya ng oras? }\end{array}$ & \begin{tabular}{|l|} 
Labis-labis \\
Labis \\
Bahagya \\
Walang-wala
\end{tabular} & $\begin{array}{l} \\
\square \\
\square \\
\square \\
\square\end{array}$ & Hindi angkop & 口 \\
\hline
\end{tabular}

Mangyaring suriin kung nasagot mo ang BAWAT tanong. Salamat.

(C) AY Finlay, GK Khan, Abril 1992. Hindi ito dapat kopyahin nang walang pahintulot ng mga may-akda. 